\title{
Effects of Detergent (Alkylbenzenesulfonate) on the Haematology of Clarias Gariepinus
}

\author{
Idowu E. ${ }^{1}$., Adewumi A. A ${ }^{2}$. and Babalola A. E. ${ }^{3}$ \\ Department of Zoology and Environmental Biology, Faculty of Science, Ekiti State Uuniversity, Nigeria
}

\begin{abstract}
The general problems of the detergent with emphasis on the haematology were investigated on Clarias gariepinus (post-juvenile) with mixed different concentrations of detergent in their compounded feed. The fish was grouped into six sets, comprising of 20 fish samples each. The control sample (sample A) was given normal feed composition with zero percent detergent concentration. The fish had access to feed for about 4 weeks for the test experiment. The haematology analysis of the exposed fish showed marked reduction in the packed cell volume (28, 13, 26, 26, 28 and 24\%) for $0-10 \%$ of detergent concentration respectively, haemoglobin ( 9.4, 4.3, 8.6, 8.6, 8.6 and $6.7 \mathrm{~g} / \mathrm{dL}$ ), white blood cell, red blood cell and differentials. The blood of the exposed fish had close dependent hypochromasia, macrocytosis, microcytosis, eosinophilia and arisocytosis. A significant difference also exists between the blood parameters of the control (initial) fish and the blood parameters of the fish exposed to various concentrations of detergent i.e. PCV $\left(0.26^{a}\right.$ and $\left.0.24^{a}\right)$, $W B C\left(10167^{a}\right.$ and $\left.9000^{a}\right), R B C\left(3.31^{a}\right.$ and $\left.3.07^{a}\right)$. The result of this research highlighted health hazards of detergent to $C$. gariepinus.
\end{abstract}

Key Words: Alkybenzenesulphonate, Clarias gariepinus, health hazards, heamatological parameters

\section{Introduction}

African Catfish (Clarias gariepinus) is one of the most important fish species currently being cultured both inside and outside its natural range of tropical and subtropical environments [1]. Positive attributes such as resistance to diseases, high fecundity and ease of larval production in captivity make it of commercial importance in agriculture [2].

There are thousands of chemicals products available for use in the World, these include: waxes, wax removers, paints, paints remover, bleaches, baking soda, detergents and many other products [3]. Of these, one thousand substances have been listed as pollutants in freshwater ecosystem and these include domestic sewage, farm manures, pesticides, detergents, food processing wastes, oils, polychlorinated biphenyl's (PCNS) [4]. In industries where chemicals are been produced, their waste products are passed into nearby water body and heavy chemicals which have not been neutralized are also passed into water body which are very dangerous to aquatic organisms even non-aquatic species including man [5]. Blood is a good indicator to determine the health of an organism [6]. It also acts as pathological reflector of the whole body; hence haematological parameters are important in diagnosing the functional status of exposed animal to toxicants [6].

A detergent is a surfactant or a mixture of surfactants with "cleaning properties in dilute solutions". These substances are usually alkylbenzenesulfonates, a family of compounds that are similar to soap but are more soluble in hard water because the polar sulfonate (of detergents) is less likely than the polar carboxyl (of soap) to bind to Calcium and other ions found in hard water. Detergents like soap, work because they are amphoteric (having the characteristics of both acid and base), partly hydrophilic (polar) and partly hydrophobic (non-polar) [7].

Detergents are made up of chemical substances like disodium trioxocarbonate (IV) $\left(\mathrm{Na}_{2} \mathrm{CO}_{3}\right)$ and disodium tetraoxosulphate (vi) $\left(\mathrm{Na}_{2} \mathrm{SO}_{4}\right)$. In the synthesis of each chemical that is made up of "sunlight" detergent it can be found that $\mathrm{Na}_{2} \mathrm{CO}_{3}$ are both acid salt and soluble in both cold and warm water but $\mathrm{Na}_{2} \mathrm{SO}_{4}$ are more acidic in reaction than $\mathrm{Na}_{2} \mathrm{CO}_{3}$ due to the presence of sulphate, sunlight detergent is a bleaching agents which are acidic or slightly acidic in nature

Synthetic detergents were first used in the 1930s, but it was not until 1950s and later that they became popular with large quantities entering aquatic ecosystem (Abel, 2006). The use of detergents in houses and factories may result in contamination or pollution of aquatic ecosystem, which may cause serious environmental problem [8]. Detergents are classified basically into three principal chemical types which are; Anionic detergents (alkylbenzenesulfonates), Cationic Detergents and Non-Ionic Detergents

Many authors have worked on heamatological studies of different fish species; these include the work of [9] on the effect of an acute and chronic toxicity of four commercial detergents on the freshwater fish Gambusa affinis. The author reported that all the four commercial detergents have toxic effects on the behaviuor, mortality and red blood cell count of this species. [10] Researched on changes in haematological parameters of Clarias gariepinus exposed to lead poisoning by exposing juveniles to sub lethal lead poisoning. 
The author observed that the haemoglobin concentration decreased significantly with increasing lead concentration and with duration and that there was a significant leucocytosis as the test concentration increased and also with duration.

The work of [11] on growth response of $C$. gariepinus exposed to water soluble fraction of detergent and diesel showed that the sub-lethal concentration effect reduces the growth of $C$. gariepinus. Detergent showed the highest mortality within the first 24 hours. Other behavioral symptoms such as increased operculum beat, erratic swimming, loss of equilibrium and gasping for air were noticed. [12] Also studied the toxicity of linear alkylbenzenesulphate (LAS) detergent on $C$. gariepinus fingerlings by using static bioassays and continuous aeration over a period of $96 \mathrm{~h}$. The result of the author revealed that the fish exhibited several behavioural changes before death such as restlessness, rapid swimming and loss of balance, respiratory distress and hemorrhaging of gill filaments amongst others.

Experimental studies on the toxicity of detergent to fishes suggest that some of the readily decomposed detergents are more toxic to fishes than the biological harder detergents: for example tetrapropylene benzensulphonate [11]. Blood cell responses are important indicators of changes in the internal and/or external environment of the fish. In fish, exposure to chemical pollutants induces either increase or decrease in the haematological and some biochemical parameters $[13,14]$. Thus, the changes in the haematological parameters are good indicators of changes in the water quality. Blood often exhibit pathological changes before the appearance of any external symptom of toxicity.

This work aimed at studying the effects of detergent (alkylbenzenesulfonate) on the haematology of Clarias gariepinus with particular references to parameters such as packed cell volume (PCV), Haemoglobin, White blood Corpuscles (WBC), Red Blood Corpuscles (RBC), Lipid profile, Glucose level and differentials.

\section{Materials and Methods}

\subsection{Study population}

A total of 120 samples of $C$. gariepinus which was post-juvenile were used

\subsection{Test substance}

The detergent (sunlight) used in this study was bought from Bisi Market in Ado-Ekiti, Ekiti State. The chemical constituents of the detergent as stated on the detergent nylon are: Surfactants, Sodium sulfate, Sodium carbonate, Optical brighteners, phosphate, poly-carboxylates and enzymes.

\subsection{Collection and acclimatization of the fish}

Apparently healthy fishes of $C$. gariepinus of mean weight $60 \mathrm{~g}$ was obtained from Adebayo's fish farm, Afao-Ekiti in Ekiti State and transported in an aerated container to the laboratory in Ekiti State University. The fish was acclimatized for 2 weeks in plastic container containing clean dechlorinated well water which was changed every three days in order for the fish to adapt to the laboratory environmental condition before the commencement of the study. Since the samples were collected in the same farm, they were fed with the same feed ( $2 \mathrm{ml}$ fish feed) two times daily (morning and evening). The left over feed and faeces were siphoned off promptly and dead fish were promptly removed to prevent contamination.

\subsection{Preparation of test}

The toxicant used "sunlight" detergent was in powdery form and whitish in colour. The detergent was weighed with an analog weighing balance from $0-10 \%$ (i.e. $10 \mathrm{~g}-100 \mathrm{~g}$ respectively) for the six treatments used. Fish meal was $72 \%$ which is of the same proportion for the treatments. Salt, oil, Soya and Vitamin premix were also weighed at a particular proportion and maize was weighed at different proportion. Maize was grinded, measured, and mixed with the vegetable oil, salt, sunlight, soya and fishmeal which were later formed into pellets. Fishmeal was $72 \%$, Salt $1 \%$ i.e. $10 \mathrm{~g}$, Oil $2 \%$ i.e. $20 \mathrm{~g}$, Vitamin premix $1 \mathrm{~g}$ and Sunlight was in different percentages; $0 \%, 1 \%, 2.5 \%, 5 \%, 7.5 \%$ and $10 \%$.

\subsection{Methods}

The fish was distributed randomly at the rate of ten per container using hand net. Two containers were used for each concentration comprising ten treatment containers and two control containers. Each container contains 15 litres of water and prior to addition of the toxicant, volume of toxicant introduced was removed from each container so that the volume remains the same. For each test concentration, two different containers were used which contained the same concentration of sunlight for each fish species, there were also the control which contained water without sunlight detergent. Feeding was stopped 24hours prior to the test and also during the 96 hours testing period in order to reduce contamination due to faecal and uneaten feed materials. Observations were made on the behaviour of organism and the numbers of fish found dead were removed. 


\subsection{Collection of blood samples for haematological analysis}

The blood samples were collected by injecting the dorsal part of the fish sideward with $2 \mathrm{ml}$ syringe. The collected blood samples were dropped in Heparin bottle, EDTA bottle and Glucose bottles. The blood samples in the heparin bottle was used to determine packed cell volume, haemoglobin and white blood cell, the blood in the EDTA bottle was used to determine lipid profile, differentials and enzymes while the blood in the glucose bottle was used to determine only the glucose content in the blood sample. Cholesterol was determined according to [15]. The triglycerides were determined after enzymatic hydrolysis with lipases according to [16]. High Density Lipoprotein (HDL) according to [17], Haemoglobin (HB) and Red Blood Cell (RBC), according to [18]

\subsection{Haematological Assay Methods}

The haemoglobin was determined by the Cyanmethanemoglobin method [19] while the haematocrit was determined by the microhaematocrit method [20]. The Neubaver's improved microscopic counter was used in counting the erythrocyte after the blood was diluted with Dacie's fluid. Similarly, the leucocyte count was done using the Neubaver microscopic counter after diluting the blood with Turk's fluid. The haematological indices were calculated following [21] method.

\subsection{Parameters determined}

The parameters determined for haematological analysis were: The Packed cell volume, Haemoglobin, White Blood cell, Lipid profile, Enzymes, Glucose level and differentials.

\subsection{Statistical analysis}

One-way Analysis of Variance (ANOVA) was used to test for significant difference and correlation which was used to test for the degree of relationship between two variables at $5 \%$ level of significant.

\section{Results}

The results of the haematological examinations of the exposed fishes showed marked reduction in the blood parameters. The Oxygen demand and glucose value of the initial analysis for C. gariepinus at zero percent concentration of detergent showed an increase in the glucose level of the C. gariepinus compared to when detergent was introduced which shows a reduction in the glucose level. At zero percent of detergent concentration for initial analysis, Oxygen demand was found to be $0.20 \mathrm{mg} / \mathrm{l}$ while the glucose value was $4.8 \mathrm{mmol} / \mathrm{l}$ but when detergent was introduced, Oxygen demand was reduced to $0.11 \mathrm{mg} / \mathrm{l}$ and glucose value to $2.7 \mathrm{mmol} / \mathrm{L}$ at $1 \%$ detergent concentration in the diet. This means that there is a reduction in glucose level when detergent was incorporated with the fish diet as shown in tables 1 and 2 below.

TABLE 1: The initial analysis of oxygen demand and glucose in Clarias gariepinus fed with normal fish meal without any concentration of detergent.

\begin{tabular}{lcc}
\hline Samples & Oxygen demand $(\mathrm{mg} / \mathrm{L})$ & Glucose value $(\mathrm{mmol} / \mathrm{L})$ \\
$\mathrm{A}$ & 0.20 & 4.8 \\
\hline $\mathrm{B}$ & 0.16 & 3.2 \\
$\mathrm{C}$ & 0.18 & 4.5 \\
$\mathrm{D}$ & 0.10 & 3.1 \\
$\mathrm{E}$ & 0.12 & 3.4 \\
$\mathrm{~F}$ & 0.13 & 3.3 \\
\hline
\end{tabular}

TABLE 2: Effect of detergent on oxygen demand and the glucose of Clarias gariepinus when exposed to diet with different concentrations of detergent.

\begin{tabular}{lcc}
\hline $\begin{array}{l}\text { Detergent } \\
\text { Concentration }(\%)\end{array}$ & $\begin{array}{c}\text { Oxygen } \\
\text { demand }(\mathrm{mg} / \mathrm{L})\end{array}$ & $\begin{array}{c}\text { Glucose } \\
\text { value }(\mathrm{mol} / \mathrm{L})\end{array}$ \\
\hline 0 & 0.15 & 3.7 \\
1 & 0.11 & 2.7 \\
2.5 & 0.14 & 3.5 \\
5 & 0.08 & 2.0 \\
7.5 & 0.10 & 2.5 \\
10 & 0.10 & 2.5 \\
& $\mathrm{STD}=0.22 \mu \mathrm{l}$ & \\
\hline
\end{tabular}


The oxygen demand for glucose in $C$. gariepinus for both initial (without detergent) and final treatment (with detergent) were tested at 5\% significant level statistically, there exist no significant differences between the initial and final treatment of Oxygen demand. For glucose value, there exist significant differences as shown in table 3 below.

The triglycerides, total cholesterol, high density lipoprotein and low density lipoprotein show a normal value in the initial analysis of the chemistry of $C$. gariepinus when no detergent was introduced $(2.16,2.57,2.02$ etc.) as shown in table 4 . The triglycerides value was $1.8,2.5,1.9$ at $0,1,2 \%$ respectively for the treatments (table 5) below. When the oxygen demands and values for triglycerides, total cholesterol, high density lipoprotein and low density lipoprotein for both initial (without detergent) and final (with detergent) at 5\% level of significant statistically was tested, there exist no significant difference because Fcal is lesser than Ftab and the mean with the same superscripts are not significantly different when Duncan was used as shown in table 6 below.

TABLE 3: Glucose changes in Clarias gariepinus fed with detergent and normal diet Using ANOVA and DUNCAN test.

\begin{tabular}{lcccc}
\hline Parameters & $\begin{array}{l}\text { Initial value (without } \\
\text { Detergent) }\end{array}$ & $\begin{array}{c}\text { Final value (with } \\
\text { detergent) }\end{array}$ & F value & F tab \\
\hline Oxygen demand & $0.15^{\mathrm{a}}$ & $0.11^{\mathrm{a}}$ & 3.40 & 3.86 \\
Glucose value & $3.72^{\mathrm{a}}$ & $2.82^{\mathrm{b}}$ & 5.02 & 3.86 \\
\hline
\end{tabular}

TABLE 4: The initial analysis of the biochemical changes of Clarias gariepinus fed with diet without detergent concentration.

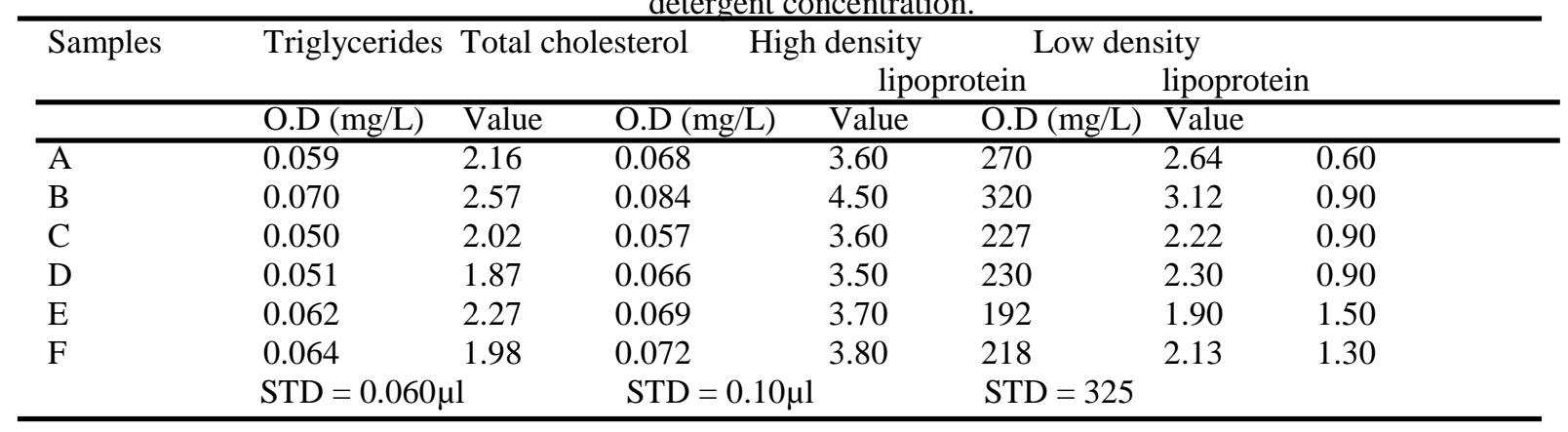

TABLE 5: Effect of detergent (Alkylbenzenesulphonate) on the biochemical changes of test Clarias gariepinus.

\begin{tabular}{|c|c|c|c|c|c|c|c|}
\hline \multirow[t]{2}{*}{$\begin{array}{l}\text { Detergent } \\
\text { concentration }(\%)\end{array}$} & \multicolumn{2}{|c|}{ Triglycerides } & \multicolumn{2}{|c|}{ Total cholesterol } & $\begin{array}{l}\text { High density } \\
\text { lipoprotein }\end{array}$ & \multicolumn{2}{|c|}{$\begin{array}{l}\text { Low density } \\
\text { lipoprotein }\end{array}$} \\
\hline & O.D (mg/L) & Value & O.D (mg/L) & Value & O.D (mg/L) & Value & \\
\hline 0 & 0.050 & 1.80 & 0.064 & 3.60 & 263 & 2.60 & 0.50 \\
\hline 1 & 0.068 & 2.50 & 0.080 & 4.50 & 316 & 3.10 & 0.90 \\
\hline 2.5 & 0.053 & 1.90 & 0.064 & 3.60 & 223 & 2.20 & 0.90 \\
\hline 5 & 0.041 & 1.50 & 0.062 & 3.50 & 226 & 2.20 & 0.80 \\
\hline 7.5 & 0.056 & 2.00 & 0.065 & 3.70 & 189 & 1.80 & 1.40 \\
\hline \multirow[t]{2}{*}{10} & 0.052 & 1.90 & 0.070 & 3.90 & 212 & 2.10 & 1.30 \\
\hline & \multicolumn{2}{|c|}{$\mathrm{STD}=0.060 \mathrm{ul}$} & \multicolumn{2}{|c|}{$\mathrm{STD}=0.094 \mathrm{ul}$} & \multicolumn{2}{|c|}{$\mathrm{STD}=325$} & \\
\hline
\end{tabular}

TABLE 6: Chemical changes in Clarias gariepinus fed with detergent and normal diet using ANOVA and

\begin{tabular}{|c|c|c|c|c|}
\hline Parameters & $\begin{array}{l}\text { Initial mean value } \\
\text { (normal diet) }\end{array}$ & $\begin{array}{l}\text { Final mean value } \\
\text { (diet with detergent) }\end{array}$ & Fvalue & Ftab \\
\hline \multicolumn{5}{|l|}{ Triglycerides } \\
\hline $\mathrm{O} . \mathrm{D}(\mathrm{mg} / \mathrm{L})$ & $0.06^{\mathrm{a}}$ & $0.05^{\mathrm{b}}$ & 1.29 & 3.86 \\
\hline Value & $2.15^{\mathrm{a}}$ & $1.93^{\mathrm{a}}$ & 1.58 & 3.86 \\
\hline \multicolumn{5}{|c|}{ Total cholesterol } \\
\hline O.D (mg/L) & $0.07^{\mathrm{a}}$ & $0.07^{a}$ & 0.17 & 3.86 \\
\hline Value & $3.80^{\mathrm{a}}$ & $3.78^{\mathrm{a}}$ & 0.01 & 3.86 \\
\hline \multicolumn{5}{|l|}{ HDL } \\
\hline$\overline{\mathrm{O} . \mathrm{D}(\mathrm{mg} / \mathrm{L})}$ & $242.83^{a}$ & $238.17^{a}$ & 0.03 & 3.86 \\
\hline Value & $2.39^{\mathrm{a}}$ & $2.33^{\mathrm{a}}$ & 0.04 & 3.86 \\
\hline LDL & $1.02^{\mathrm{a}}$ & $0.97^{\mathrm{a}}$ & 0.07 & 3.86 \\
\hline
\end{tabular}


The packed cell volume, white blood cell, red blood cell, haemoglobin and differentials values of the initial haematology for $C$. gariepinus at zero percent concentration of detergent showed an increase in the haematology level of the $C$. gariepinus compared to when detergent was introduced which showed a reduction in the haematology level. At zero percent of detergent concentration from the initial analysis, packed cell volume was found to be $30 \%$ but when detergent was introduced as treatment, packed cell volume was reduced to $24 \%$ at $10 \%$ detergent concentration. This means that there is a reduction in haematology level when detergent was introduced as shown in table 7 and 8 below.

Changes in the haematological parameters of fish fed with detergent showed a significant remarkable decrease in values compared to the fish fed with normal diet as seen in table 9.

TABLE 7: The initial analysis of the haematology of Clarias gariepinus without any concentration of detergent

\begin{tabular}{lccccccccc}
\hline Samples & $\begin{array}{c}\text { PCV } \\
(\%)\end{array}$ & $\begin{array}{l}\text { WBC } \\
\left(\mathrm{mm}^{3}\right)\end{array}$ & $\begin{array}{l}\text { RBC } \\
\left(\mathrm{mm}^{3}\right)\end{array}$ & $\begin{array}{l}\mathrm{HB} \\
(\mathrm{mg} / \mathrm{L})\end{array}$ & $\begin{array}{c}\text { O.D } \\
\text { Value } \\
(\mathrm{g} / \mathrm{dL})\end{array}$ & $\mathrm{N}$ & $\mathrm{L}$ & $\mathrm{M}$ & $\mathrm{F}$ \\
\hline $\mathrm{A}$ & 30 & 10,000 & 4.67 & 0.28 & 10.5 & 22 & 67 & 12 & 06 \\
B & 15 & 12,000 & 1.56 & 0.16 & 4.9 & 24 & 68 & 10 & 04 \\
C & 28 & 9.000 & 3.10 & 0.25 & 8.7 & 28 & 67 & 08 & 04 \\
D & 28 & 13,000 & 4.18 & 0.25 & 8.5 & 22 & 71 & 06 & 04 \\
E & 29 & 12,000 & 3.65 & 0.26 & 8.7 & 20 & 73 & 12 & 02 \\
F & 26 & 5,000 & 2.67 & 0.20 & 7.0 & 28 & 63 & 09 & 06 \\
\hline
\end{tabular}

Keys: PCV (Packed cell volume); WBC (White blood cells); RBC (Red blood cells); HB (Haemoglobin); O.D (Oxygen demand); N, M, L, F are the differentials.

TABLE 8: Effect of detergent on the haematology of Clarias gariepinus

\begin{tabular}{lcccccccccc}
\hline $\begin{array}{l}\text { Detergent } \\
\text { concentration } \\
(\%)\end{array}$ & $\begin{array}{l}\mathrm{PCV} \\
(\%)\end{array}$ & $\begin{array}{c}\mathrm{WBC} \\
\left(\mathrm{mm}^{3}\right)\end{array}$ & $\begin{array}{l}\mathrm{RBC} \\
\left(\mathrm{mm}^{3}\right)\end{array}$ & $\begin{array}{c}\mathrm{HB} \\
(\mathrm{mg} / \mathrm{L})\end{array}$ & $\begin{array}{c}\text { O.D } \\
\text { Value } \\
(\mathrm{g} / \mathrm{dL})\end{array}$ & $\mathrm{N}$ & $\mathrm{L}$ & $\mathrm{M}$ & $\mathrm{F}$ \\
\hline 0 & 28 & 8,000 & 4.46 & 0.22 & 9.4 & 20 & 66 & 10 & 04 \\
1 & 13 & 10,000 & 1.22 & 0.10 & 4.3 & 22 & 68 & 08 & 02 \\
2.5 & 26 & 8,000 & 2.95 & 0.20 & 8.6 & 26 & 66 & 06 & 02 \\
5 & 26 & 14,000 & 4.09 & 0.20 & 8.6 & 20 & 70 & 08 & 02 \\
7.5 & 28 & 10,000 & 3.21 & 0.20 & 8.6 & 18 & 72 & 10 & 00 \\
10 & 24 & 4,000 & 2.46 & 0.16 & 6.7 & 26 & 62 & 08 & 04 \\
\hline
\end{tabular}

Keys: PCV (Packed cell volume); WBC (White blood cells); RBC (Red blood cells); HB (Haemoglobin); O.D (Oxygen demand); N, M, L, F are the differentials.

TABLE 9: Haematological changes in Clarias gariepinus fed detergent and normal diet using ANOVA and

\begin{tabular}{|c|c|c|c|c|}
\hline \multicolumn{5}{|c|}{ DUNCAN test. } \\
\hline Parameters & Initial mean value & Final mean value & Fvalue & Ftab \\
\hline$\overline{\mathrm{PCV}(\%)}$ & $0.26^{\mathrm{a}}$ & $0.24^{\mathrm{a}}$ & 0.32 & 3.86 \\
\hline $\mathrm{WBC}\left(\mathrm{mm}^{3}\right)$ & $10167^{\mathrm{a}}$ & $900^{\mathrm{a}}$ & 0.42 & 3.86 \\
\hline $\operatorname{RBC}\left(\mathrm{mm}^{3}\right)$ & $3.31^{\mathrm{a}}$ & $3.07^{\mathrm{a}}$ & 0.13 & 3.86 \\
\hline Haemoglobin & $0.23^{\mathrm{a}}$ & $0.18^{\mathrm{a}}$ & 4.37 & 3.86 \\
\hline O.D & $0.23^{\mathrm{a}}$ & $0.18^{\mathrm{a}}$ & 4.37 & 3.86 \\
\hline Value & $8.05^{\mathrm{a}}$ & $7.70^{\mathrm{a}}$ & 0.10 & 3.86 \\
\hline \multicolumn{5}{|l|}{ Differentials } \\
\hline $\mathrm{N}$ & $24.0^{\mathrm{a}}$ & $22.0^{\mathrm{a}}$ & 1.07 & 3.86 \\
\hline $\mathrm{L}$ & $68.17^{\mathrm{a}}$ & $67.33^{\mathrm{a}}$ & 0.17 & 3.86 \\
\hline M & $9.50^{\mathrm{a}}$ & $8.17^{\mathrm{a}}$ & 1.32 & 3.86 \\
\hline $\mathrm{F}$ & $4.33^{\mathrm{a}}$ & $2.33^{\mathrm{a}}$ & 5.29 & 3.86 \\
\hline
\end{tabular}

Means with the same superscripts are not significantly different while means with different superscripts are significantly different.

Keys: PCV (Packed cell volume); WBC (White blood cells); RBC (Red blood cells); HB (Haemoglobin); O.D (Oxygen demand); N, M, L, F are the differentials. 


\subsection{Discussion}

\section{Discussion And Conclusion}

There was a remarkable decrease in the values of haematological parameters in C. gariepinus fed with sunlight detergent. This is in agreement with [22] that reported effect of toxicants on blood parameters in fresh water teleost fish Clarias batrachus. Similar reduction of blood parameters were made by various authors. [23] Have reported decrease in albumin in the fish Channa punctatus when exposed to imidacloprid. [24] Have noted that the RBC count decreased significantly in the fresh water fish, Labeo rohita on exposure to herbicide glyphosate. [25] Noticed the decreased haemoglobin content in the fresh water fish, Tilapia mossambica on exposure to arsenic. [26] Made similar observation in Cirrhinus mrigala exposed to detergent tide. All these observations confirm the findings of the present study

The reduction in haematological parameters is indicative of blood loss from fish fed with diet that contains detergent compared to the fish fed with normal diet, although they were not significantly different from the initial haematological values of the fish and those fed with the control diet. The standard values shown under some tables' show that the fish were probably overfed which led to the increase of their standard values.

Increase in total white blood cell (leucopomia) as observed in the fish fed with normal diet is attributed to increased production of leucocytes in the haematopoietic tissue of the kidney and perhaps the spleen. Lymphocytes are the most numerous cells comprising the leucocytes which function in the production of antibodies and chemical substances serving as defense against infection. The primary consequence of observed changes in leucocytes count in stressed fish is suppression of the immune system and increased susceptibility to disease [27]. The values for fish fed poultry litter are lower than those reported for African catfish by [28] and [29]. The anaemic condition of fish fed with detergent in this study may however be due to its protein inadequacy to meet the fish requirements, which might have inhibited erythrocyte production or increase rate of destruction. Lower haemoglobin level might decrease the ability of fish to enhance its activity in order to meet occasional demands.

When fish was subjected to statistical analysis, the values did not show significant difference and this may mean that $C$. gariepinus been a hardy species of fish might be able to tolerate moderate polluted water. The marked reduction in the blood parameters (PCV, HB, WBC and RBC) of the exposed fishes compared to the initial fishes confirms the earlier report of [30] who reported blood parameters reduction in rabbit exposed to Sodium Dodecyl Sulfate (surfactant). The toxic effect of the anionic detergent (surfactant) has been reported by [31], to cause reduction in blood parameters and weight loss. The reduction in the blood parameters was as a result of destruction of the cells of the fish by the surfactant and traces amount of heavy metals found in detergents. [32] Reported that blood and skin of an animal may be adversely affected by soaps and detergents used as anti-bacteria and insecticides because they do so by killing the cells of the germs and insects.

\subsection{Conclusion}

In conclusion, the present study revealed that detergent incorporated in diet of fish fed C. gariepinus created haematological disturbances which ultimately resulted in anaemic conditions.

\section{Recommendation}

Based on the information gathered in this study, it is recommended that waste disposal into the water as well as introduction of pollutants or toxicant such as detergent from laundry activities of the villagers should be checked.

\section{References}

[1]. M.A. Adewolu, C. A. Adeniji, and B.A. Ademola, Feed utilization, growth and survival of Clarias gariepinus (Burchell 1822) cultured under different photoperiods Aquaculture. Vol. 283, 2008, 64 - 67.

[2]. G.S. Haylor, Controlled hatchery production of Clarias gariepinus (Burchell 1882), growth and survival of fry at high stocking density. Aquaculture Fishery Management. Vol(22), 1991, 405 - 422.

[3]. E.M. Hill, K.L .Evans, J. Horward, P. Rostkowski, F.O. Oladapo, R. Gibson, J.A. Shears, and C.R.Tyler, Profiles and some (anti) androgenic compounds in fish exposed to waste water treatment works effluents. Environmental Science and Technology. Vol 44(3), 2010, 1137 - 1143.

[4]. P.D. Abel, Toxicity of synthetic detergents to fish and aquatic invertebrates. Journal of Fisheries Biology. Vol(6), 2006, 279 - 298

[5]. M. Gholami, S.M.R. Fatemi, M. Falahi, A. Esmaili, and A. Mashinchiy, Effects of heavy metals (copper and cadmium) and detergent (LAS) on white fish fry Rutilus frisii Kutum. Resources journal environmental toxicology. Vol(4), 2010,231 - 236.

[6]. P.K. Joshi, M. Bose, and D. Harish, Changes in certain haematological parameters in a siluroid catfish Clarias batrachus (Linn) exposed to cadmium chloride. Pollution Resources. Vol 21(2), 2002a, $119-122$.

[7]. D. Werner, R. Arno, S. Andrea, and R. Klaus (2002) 'Automotive fuels' in Ullmann's Encyclopedia of Industrial Chemistry, $115-116$.

[8]. K.T. Pickering, and L.A. Owen, An introduction to global environmental issues. Rout ledge, London, UK., ISBN-13: $9780415102278,1994,390$.

[9]. P. Saxena, Effect of an acute and chronic toxicity of four commercial detergents on the freshwater fish Gambusa affinis. Biard and Gerard. J. Environ. Sci. Eng. Vol 47(2), 2005, $119-124$. 
[10]. N.S. Oluah, The effect of sub-lethal cadmium on the haematological parameters of freshwater catfish, Clarias gariepinus (Pisces: Clariidae). J. Sci. Agric. Food Tech. Environ. Vol(1), 2001, 15 - 18.

[11]. I.K. Esenowo and O. A. Ugwumba, Growth response of catfish (Clarias gariepinus) exposed to water soluble fraction of detergent and diesel oil. Environmental Research Journal, vol(4), 2010, 298:301

[12]. O. Ogundele, J.A. Ihuahi, F.S. Omojowo, and P. Bitrus, Toxicity of linear alkylbenzenesulphonate (LAS) detergent to Clarias gariepinus fingerlings. In $19^{\text {th }}$ annual conference of the Fisheries Society of Nigeria (FISON), 2005, $143-145$.

[13]. V. Luskova, Annual cycle and normal values of haematological parameters in fishes. Acta Sci. Nat. Brno. Vol(31,) 1997, 7078.

[14]. P.A. Annune, and F.T.A. Ahuma, Haematological changes in mudfish, Clarias gariepinus (Burch) exposed to sublethal concentrations of copper and lead. Journal of Aquatic Science. Vol(13), 1998, 33 - 36.

[15]. D.S.Jacobs, B.L. Kasten, W.R. De mott, (eds, Lexi-comp. inc. Hudson leveland); 1990): In laboratory and test handbook, 219.

[16]. M. F. Lopes-Virella,P. Stone, S. Elis, J. A. Colwell, Cholesterol determination in high density Lipoproteins separated by three different methods. Clin Chemistry Vol(23), 1977, 882- 884

[17]. N. Richmond, High density lipoprotein. Clinical chemistry; Vol(19), 1973, $1350-1356$.

[18]. L. DaRos, C. Nasci, G. Campesan, P. Sartorello, G. Stocco, and A. Menetto, Effects of linear alkylbenzene sulphonate (LAS) and cadmium in the digestive gland of mussel, Mytilus spp. Marine Environmental Research. Vol (39), $1995,321-324$.

[19]. P.C. Blaxhall and K. W. Daisley, (1973). Routine haematological methods for use with fish blood. J. Fish Biol 5, 1973, 771-781

[20]. P.C. Allen, Effects of acute exposure to cadmium (II) chloride and lead (II) chloride in the haematological profile of Oreochromis aureus (Steindachner). Comp. Biochem. Physiol. Vol(105), 1993, 213 - 217.

[21]. L. Tort and P. Torres (1988). The effects of sub lethal concentration of Cadmium on haematological parameters in the dog fish, Scyliorhinus canicula Journal of fish boil 32(2), 1988, 277-282

[22]. P.K. Joshi, D. Harish and M. Bose, Effect of lindane and malathione exposure to certain blood parameters in a fresh water teleost fish Clarias batrachus. Pollution sources. Vol 21(1), 2002b, 55 - 57.

[23]. V. Anilkumar and C. Janaiah, Imidacloprid Exposure atters serum biochemical parameters in Channa punctatus (Bloch). Bulletin of Pure and Applied Sciences, vol. 28A(2), 2009, 123-130.

[24]. K. Jayaseelan, K. Muthukumaravel and R. Rajakumar, Toxic effects of herbicide glyphosate on haematological parameters in the fresh water fish, Labeo rohita. J.Ecotoxicol. Environ. Monit., 21(3), 2001277-285.

[25]. M. Soundararajan, and G. Veeraiyan, Effecst of heavy metal arsenic on haematological parameters of fresh water fish, Tilapia mossambica. Int. J. Modn. Res. Revs., 2(3), 2014, 132-135.

[26]. J. Vasanthi, K. Pechiammal and S. Binukumari, Toxicity Effect of the Detergent Tide on the Haematological Parameters of The Freshwater Fish Cirrhinus mrigala. Int J Recent Sci Res. 7(1), 2016, 8523-8526.

[27]. G.A. Wedemeyer and J.W. Wood, Stress as a predisposing factor in fish diseases. Fish Disease Leaflet 38, 1974,749

[28]. S.A. Agbede, A.O.Ogunsanmi, V.O. Taiwo, J.A. Oso and T.I. Ogundipe, Toxic effects of poultry faeces on Clarias gariepinus broodstock. Tropical Veterinarian, 1999, 17:181 - 191.

[29]. A.O. Oyelese, V.O. Taiwo, A.O. Ogunsanmi, and E.O. Faturoti, Toxicological effects of cassava peels on haematology, serum biochemistry and tissue pathology of Clarias gariepinus fingerlings. Tropical Veterinarian. Vol(17), $1999,17-30$.

[30]. M.A.M. Wadaan, and M. Mubarak, Blood chemistry an evidence of the toxic effects of anions surfactant sodium dodecyl sulfate. Asian J. Scientific Res. Vol(2),2009, 113 - 118.

[31]. C. Dehelean, V. Nastase, A. Dragomirescu, A. Heges, and E. Dinte, Skin toxicity of sodium lauryl sulfate as evidenced in an animal model. Rev. Med. Chir. Soc. Med. Nat. Iasi., Vol(108), 2004, $169-172$.

[32]. S. Riaz, A. Ahmad and S. Hasnain, Antibacteria activity of soaps against daily encountered bacteria. Afr. J. Biotechnol. Vol(8), 2009, 1431 - 1436. 